\title{
Tidal and seasonal forcing of dissolved nutrient fluxes in reef communities
}

\author{
Renee K. Gruber ${ }^{1}$, Ryan J. Lowe ${ }^{2,3}$, and James L. Falter ${ }^{2,3}$ \\ ${ }^{1}$ The Australian Institute of Marine Science, Townsville, Queensland 4810, Australia \\ ${ }^{2}$ The Oceans Institute, University of Western Australia, Crawley, Western Australia 6009, Australia \\ ${ }^{3}$ The ARC Centre of Excellence for Coral Reef Studies, Crawley, Western Australia 6009, Australia
}

Correspondence: Renee K. Gruber (r.gruber@aims.gov.au)

Received: 17 September 2018 - Discussion started: 24 September 2018

Revised: 12 April 2019 - Accepted: 27 April 2019 - Published: 13 May 2019

\begin{abstract}
Benthic fluxes of dissolved nutrients in reef communities are controlled by oceanographic forcing, including local hydrodynamics and seasonal changes in oceanic nutrient supply. Up to a third of reefs worldwide can be characterized as having circulation that is predominantly tidally forced, yet almost all previous research on reef nutrient fluxes has focused on systems with wave-driven circulation. Fluxes of dissolved nitrogen and phosphorus were measured on a strongly tide-dominated reef platform with a spring tidal range exceeding $8 \mathrm{~m}$. Nutrient fluxes were estimated using a one-dimensional control volume approach, combining flow measurements with modified Eulerian sampling of waters traversing the reef. Measured fluxes were compared to theoretical mass-transfer-limited uptake rates derived from flow speeds. Reef communities released $2.3 \mathrm{mmol} \mathrm{m}^{-2} \mathrm{~d}^{-1}$ of nitrate, potentially derived from the remineralization of phytoplankton and dissolved organic nitrogen. Nutrient concentrations and flow speeds varied between the major benthic communities (coral reef and seagrass), resulting in spatial variability in estimated nitrate uptake rates. Rapid changes in flow speed and water depth are key characteristics of tidedominated reefs, which caused mass-transfer-limited nutrient uptake rates to vary by an order of magnitude on timescales of $\sim$ minutes-hours. Seasonal nutrient supply was also a strong control on reef mass-transfer-limited uptake rates, and increases in offshore dissolved inorganic nitrogen concentrations during the wet season caused an estimated twofold increase in uptake.
\end{abstract}

\section{Introduction}

Reef organisms remove nutrients from overlying waters for essential metabolic and biogeochemical processes, which enable them to accumulate biomass and ultimately support broader marine food webs (McMahon et al., 2016; Parrish, 1989). Reef waters have carbon concentrations that are orders of magnitude greater than nitrogen $(\mathrm{N})$ and phosphorus $(\mathrm{P})$, and thus benthic community productivity is generally limited by the rates at which organisms can acquire $\mathrm{N}$ and $\mathrm{P}$ (Atkinson and Falter, 2003; Larned, 1998; Smith, 1984). Suspended $\mathrm{N}$ and $\mathrm{P}$ can be categorized into dissolved inorganic (DIN, DIP), dissolved organic (DON, DOP), and particulate organic (PON, PP) fractions, which are generally utilized by different groups of organisms. Primary producers take up dissolved inorganic nutrients in the forms of nitrate and nitrite $\left(\mathrm{NO}_{x}\right)$, ammonium $\left(\mathrm{NH}_{4}^{+}\right)$, and phosphate (DIP), which are found at low concentrations in reef waters.

The majority of studies on reef nutrient dynamics have focused on the dissolved inorganic species, as these are tightly coupled to reef productivity (D'Elia and Wiebe, 1990; Szmant, 2002). Research over the last 2 decades has shown that the upper limit of DIN and DIP uptake on reefs is physically constrained by mass transfer, a term that refers to the transfer of solutes in the water column across diffusive boundary layers surrounding the tissue surface of an organism (Bilger and Atkinson, 1992; Hurd, 2000). Nutrient uptake in reef waters is typically mass transfer limited (i.e., the biological demand for nutrients is higher than the physical rate at which they can be supplied). Therefore, the uptake rate has a first-order relationship with nutrient concentration and is a function of water velocity, bottom roughness properties, and diffusion 
characteristics of the solute (Atkinson, 2011). Due to the dependency of mass-transfer-limited nutrient uptake on flow speed, the local hydrodynamic conditions within a reef directly affect uptake rates of DIN and DIP (Atkinson and Bilger, 1992; Baird et al., 2004; Falter et al., 2016; Reidenbach et al., 2006; Thomas and Atkinson, 1997), and these uptake rates can be predicted for a particular reef given sufficient information (Falter et al., 2004; Zhang et al., 2011). However, validating these models with observations from living systems remains a major challenge, as measurements must occur at spatial and temporal scales relevant to reef circulation, and in situ uptake is often confounded by simultaneously occurring biogeochemical processes that release DIN and DIP into the water column (Atkinson and Falter, 2003; Wyatt et al., 2012).

Ocean-derived dissolved organic $\mathrm{N}$ and $\mathrm{P}$ compounds are generally thought to be refractory or too energetically intensive for organisms to utilize (Knapp et al., 2005); thus, DON tends to dominate the nitrogen pool and DOP concentrations are generally low and similar to DIP (Furnas et al., 2011). However, studies on DON uptake have provided mixed results: some have measured a net production of DON by reef communities (Cuet et al., 2011a; Tanaka et al., 2011), while others have found evidence that primary producers (Vonk et al., 2008), corals (Grover et al., 2008), and filter feeders (Rix et al., 2017) can directly utilize some DON compounds. Finally, particulate $\mathrm{N}$ and $\mathrm{P}$ pools in reef waters are generally dominated by small phytoplankton $(<2 \mu \mathrm{m})$ and bacterial cells, and are an important source of nutrients for reef suspension and filter-feeding organisms (Houlbrèque et al., 2006; Ribes et al., 2005; Wyatt et al., 2010).

Accurate measurements of nutrient uptake in natural reef communities are still relatively limited and are just beginning to incorporate spatial and temporal variability in forcing conditions (Lowe and Falter, 2015), such as gradients in wave energy across a reef or seasonal changes in local oceanic nutrient concentrations (e.g., Wyatt et al., 2012). While many studies have assessed nutrient dynamics in reefs experiencing long-term nutrient enrichment (Cuet et al., 2011a; Furnas, 2003; Paytan et al., 2006; Tait et al., 2014), relatively little work has focused on systems experiencing natural pulses in nutrient delivery from processes such as coastal upwelling (Andrews and Gentien, 1982; Stuhldreier et al., 2015; Wyatt et al., 2012) or internal waves (Green et al., 2019; Leichter et al., 2003; Wang et al., 2007). Additionally, the majority of reef research to date has occurred on reefs, whose circulation patterns and residence times are mainly driven by wavebreaking on the fore-reef (Monismith, 2007). However, the circulation of up to a third of reefs worldwide has been estimated to be tide-dominated, defined as the case where annual mean significant wave height (offshore of the reef) is less than the mean tidal range (Lowe and Falter, 2015). Reefs that are strongly tide-dominated can experience substantial variability in flow speeds and water depths over a single semidiurnal tidal cycle (Lowe et al., 2015), which suggests that mass-transfer-limited nutrient uptake rates (and other biological processes) would also vary throughout the tidal cycle.

The Kimberley coastal region (located in remote northwestern Australia) has a macrotidal regime where spring tidal ranges can reach $12 \mathrm{~m}$ in some locations (Kowalik, 2004). The region contains thousands of islands with a total reef area estimated to be $\sim 2000 \mathrm{~km}^{2}$ (Kordi and O'Leary, 2016), inhabited by diverse coral reef and seagrass communities (Richards et al., 2015; Wells et al., 1995). Recent work has revealed the strongly tide-dominated circulation that can occur on Kimberley reef platforms (Lowe et al., 2015). When the tidal amplitude (half the tidal range) is greater than the reef elevation relative to mean sea level, water levels drop below the reef for portions of each tidal cycle, and this "truncation" of the semidiurnal tide results in asymmetric phase durations ( $\sim 10 \mathrm{~h}$ ebb and $\sim 2 \mathrm{~h}$ flood) and flow speeds (Lowe et al., 2015). Extended periods of low water depth on reef platforms such as Tallon Island can cause communities to experience high irradiances that result in diel temperature changes up to $11^{\circ} \mathrm{C}$ (Lowe et al., 2016) and dissolved oxygen fluctuations among the most extreme measured worldwide (Gruber et al., 2017). Recent measurements of coral calcification (Dandan et al., 2015), seagrass productivity (Pedersen et al., 2016), reef community metabolism (Gruber et al., 2017), and particulate nutrient uptake (Gruber et al., 2018) have been published from tide-dominated systems, yet little is currently known about how these large tides control fluxes of dissolved nutrients. The objectives of this study were to (1) measure fluxes of dissolved $\mathrm{N}$ and $\mathrm{P}$ on a tidally forced reef, (2) compare measured rates to maximum potential uptake predicted by mass-transfer theory, and (3) compare tidal forcing (velocity and water depth changes) and oceanic forcing (seasonal changes in nutrient concentration) of masstransfer-limited uptake rates. This work will provide some preliminary insight into the magnitudes, variability, and temporal scales of nutrient cycling on tide-dominated reefs.

\section{Methods}

\subsection{Field site}

A series of field experiments were conducted in the western Kimberley region at Tallon Island, which contains a large intertidal reef platform (surface area $2.2 \times 10^{6} \mathrm{~m}^{2}$ ) on its eastern side (Fig. 1). The platform is elevated slightly $(25 \mathrm{~cm})$ above mean sea level, and the seaward rim is $10 \mathrm{~cm}$ shallower than the rest of the platform; this feature, coupled with bottom friction, prevents reef benthic communities from becoming emersed during low tide (Lowe et al., 2015). The platform is covered with a series of regular shore-parallel ridges $\sim 0.15-0.25 \mathrm{~m}$ in height and contains two benthic communities: a seagrass-dominated inner zone (from the fringing mangrove shoreline to $400 \mathrm{~m}$ landward of the reef crest) and a coral reef outer zone ( $200 \mathrm{~m}$ wide extending shoreward 


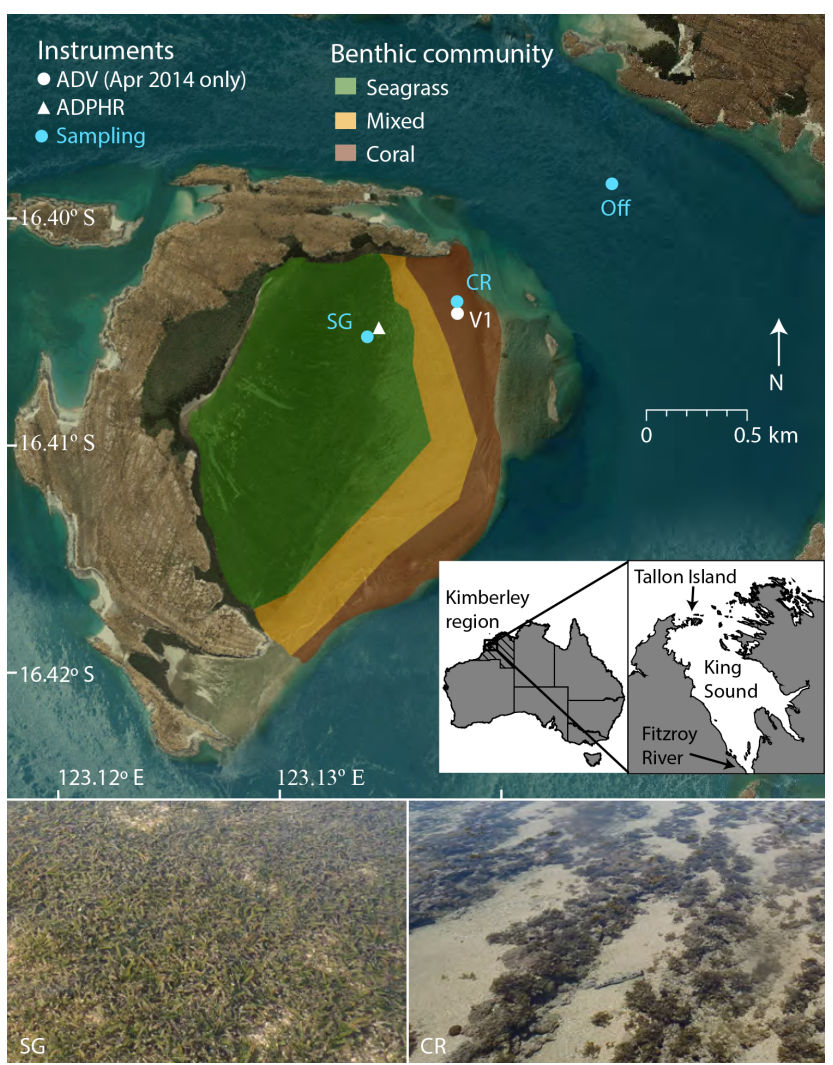

Figure 1. Deployment locations of hydrodynamic instrumentation and water sampling locations on the Tallon reef platform and offshore. Inset shows Tallon Island location in the western Kimberley region of Australia. ADV refers to acoustic Doppler velocimeter and ADPHR refers to acoustic Doppler profiler.

from the crest). Between these distinct communities, a $200 \mathrm{~m}$ zone of rubble and sand occurs where the seagrass and coral reef communities mix (Fig. 1). Enhalus acoroides is found with Thalassia hemprichii in the seagrass zone (Wells et al., 1995). The coral community contains brown foliose macroalgae (predominantly Sargassum spp.), a diverse assemblage of small hard corals ( $\sim 5-10 \%$ cover), soft coral, coralline macroalgae, and crustose coralline algae.

The Kimberley region experiences a subtropical climate, so field experiments at Tallon reef were conducted during the dry (5-20 October 2013) and wet seasons (4-9 February 2014). Nutrient concentrations were measured from duplicate filtered water samples (Table 1) and were collected around hydrodynamic instrumentation, forming a onedimensional control volume, as detailed below (see also Gruber et al., 2017). This approach allowed estimation of dissolved nutrient fluxes (the net uptake or release of nutrients) across the reef benthos. Estimates of uptake of DIN and DIP at the limits of mass transfer were made using hydrodynamic data over a spring-neap cycle $(\sim 15 \mathrm{~d})$ collected during the hydrodynamic study of Lowe et al. (2015) and nutrient concentrations from water sampling during the October and February field experiments. Flows on the reef platform are strongly tide-driven and can be predicted based on water depth and tidal phase (Lowe et al., 2015); given that spring and neap tidal ranges were very similar between October and April experiments, velocity measurements from April can be considered representative of velocities in October. This paper presents tidal phase-averaged data as a way to visualize hydrodynamic and biogeochemical measurements that tend to fluctuate with the phase of tide. Phase-averaged values in this study are ensemble averages of all measurements occurring at a given point in the semidiurnal (M2) tidal cycle (e.g., the average of all measurements taken during low tide).

\subsection{Dissolved nutrient sampling}

Water samples were collected during both field experiments for analysis of dissolved nutrient concentrations in offshore and reef flat waters. Eulerian sampling occurred at three stations (Fig. 1): the coral zone (CR), the seagrass zone (SG), and offshore of the reef in adjacent waters (Off). Offshore samples were collected throughout the semidiurnal tidal cycle on days of sampling (Table 1). Collecting water samples on the reef platform was not feasible during periods of peak flood and ebb, which occurred 0-1 and 4-6h after the onset of reef flooding, respectively (when offshore waters first overtopped the reef crest). Rapid changes in water depth during these tidal phases caused current speeds exceeding $0.8 \mathrm{~m} \mathrm{~s}^{-1}$ (Fig. 2), which made for unsafe conditions for sampling by foot or boat. Reef sampling was conducted during the remaining $9 \mathrm{~h}$ of each tidal cycle, either by foot when water depths were low $(\sim 0.4-0.6 \mathrm{~m})$ or by boat during high tide (1-4 $\mathrm{h}$ from the onset of reef flooding).

Water samples were collected from just beneath the water surface for analysis of dissolved nutrients. A $50 \mathrm{~mL}$ syringe (pre-rinsed with reef water) was used to collect water, which was immediately filtered (Minisart, pore size $0.45 \mu \mathrm{m}$ ) into $30 \mathrm{~mL}$ pre-rinsed tubes. These samples were placed in darkness on ice and were frozen upon return to the field station (several hours); samples were transported and stored frozen until analysis at the laboratory $(<4$ weeks from the end of the field experiment). Analyses of nitrate and nitrite $\left(\mathrm{NO}_{x}\right)$, ammonium $\left(\mathrm{NH}_{4}^{+}\right)$, and inorganic phosphorus (DIP) concentrations were determined on a flow-injection autoanalyzer (Lachat QuikChem 2500) using standard methods (Strickland and Parsons, 1972). Total dissolved nitrogen was determined by persulfate oxidation of filtered samples (Valderrama, 1981), followed by analysis of nitrate as above. Dissolved organic nitrogen (DON) was estimated from the total dissolved nitrogen less $\mathrm{NO}_{x}$ and $\mathrm{NH}_{4}^{+}$. All nutrient concentrations presented are the mean of duplicate samples.

\subsection{Control volume approach}

The control volume (CoVo) technique utilizes flow measurements and modified Eulerian sampling of solutes or particles 
Table 1. Summary of mean (italics indicate standard deviation) conditions in offshore waters during October and February field experiments. Nutrient species measured are nitrate and nitrite $\left(\mathrm{NO}_{x}\right)$, ammonium $\left(\mathrm{NH}_{4}^{+}\right)$, dissolved inorganic phosphorus (DIP), and dissolved organic nitrogen (DON). Number of duplicate nutrient samples collected is shown for offshore (Off), coral (CR), and seagrass (SG) sites.

\begin{tabular}{|c|c|c|c|c|c|c|c|c|c|}
\hline & \multicolumn{2}{|c|}{ Tide range $(\mathrm{m})^{*}$} & \multirow[b]{2}{*}{ Salinity } & \multirow[b]{2}{*}{$\begin{array}{r}\text { Temp } \\
\left({ }^{\circ} \mathrm{C}\right)\end{array}$} & \multicolumn{4}{|c|}{ Concentration $(\mu \mathrm{M})$} & \multirow[b]{2}{*}{$\begin{array}{l}\text { Number of } \\
\text { samples (site) }\end{array}$} \\
\hline & Spring & Neap & & & $\mathrm{NO}_{x}$ & $\mathrm{NH}_{4}^{+}$ & DIP & DON & \\
\hline $\begin{array}{l}5-20 \text { Oct } \\
2013\end{array}$ & 6.7 & 2.6 & $\begin{array}{r}34.7 \\
(0.02) \\
\end{array}$ & $\begin{array}{r}27.8 \\
(0.29) \\
\end{array}$ & $\begin{array}{r}0.40 \\
(0.09) \\
\end{array}$ & $\begin{array}{r}0.37 \\
(0.12) \\
\end{array}$ & $\begin{array}{r}0.18 \\
(0.02) \\
\end{array}$ & $\begin{array}{r}12.7 \\
(2.4) \\
\end{array}$ & $\begin{array}{l}26 \text { (Off), } 36 \\
(\mathrm{CR}), 33 \text { (SG) }\end{array}$ \\
\hline $\begin{array}{l}\text { 4-9 Feb } \\
2014\end{array}$ & 7.0 & 2.1 & $\begin{array}{r}34.2 \\
(0.06)\end{array}$ & $\begin{array}{r}30.1 \\
(0.06)\end{array}$ & $\begin{array}{r}0.92 \\
(0.19)\end{array}$ & $\begin{array}{r}0.69 \\
(0.23)\end{array}$ & $\begin{array}{r}0.15 \\
(0.03)\end{array}$ & $\begin{array}{l}10.7 \\
(2.5)\end{array}$ & $\begin{array}{l}15 \text { (Off), } 14 \\
(\mathrm{CR}), 13(\mathrm{SG})\end{array}$ \\
\hline
\end{tabular}

* Difference between max and min water levels.

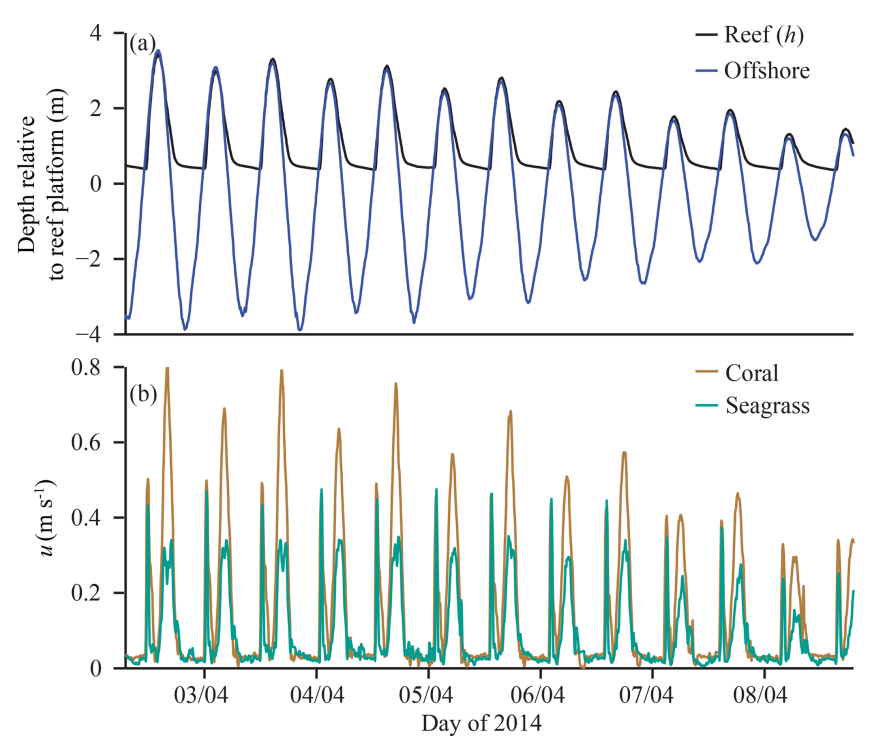

Figure 2. Selected time series of spring-neap transition showing (a) water depths $(h)$ on the reef (measured in the seagrass zone) and offshore, with depth-averaged flow speed $u$ in (b) coral- and seagrass-dominated zones.

to derive in situ benthic flux estimates. Tallon reef platform is well-suited to a one-dimensional CoVo approach due to long periods (approximately $10 \mathrm{~h}$ of each semidiurnal tidal cycle) of consistent flow direction; nutrient sampling may thus be conducted at "upstream" and "downstream" sites during these periods. A similar approach has previously been used on Tallon reef to estimate its benthic metabolism (Gruber et al., 2017) and particulate material uptake (Gruber et al., 2018) rates. A bottom-mounted acoustic Doppler current profiler (Nortek Aquadopp HR) was stationed near SG (Fig. 1) and measured current velocity and water depth $(h)$ at $1 \mathrm{~Hz}$ and $0.03 \mathrm{~m}$ bins. Depth-averaged flow speeds $(u)$ were averaged at 5 min intervals. During the reef's extended $\sim 10 \mathrm{~h}$ ebb tide, water drained off the platform in a consistent northeast direction $\left(80^{\circ} \pm 30^{\circ}\right.$, mean \pm standard deviation), along which the water sampling stations were aligned.
Depth-averaged current velocity was rotated in this ebb flow direction $\left(u_{x}\right)$ and transport $q_{x}$ was estimated as follows:

$q_{x}=u_{x} h$,

assuming negligible horizontal dispersion. The net flux $J_{\text {net }}$ (in mmol $\mathrm{N}$ or $\mathrm{P} \mathrm{m}^{-2} \mathrm{~d}^{-1}$ ) of each nutrient species $\left(\mathrm{NO}_{x}\right.$, $\mathrm{NH}_{4}^{+}$, DIP, and DON) into the benthos was estimated as follows:

$-J_{\text {net }}=\bar{h} \frac{\mathrm{d} \bar{C}}{\mathrm{~d} t}+q_{\mathrm{x}} \frac{\left(C_{\mathrm{CR}}-C_{\mathrm{SG}}\right)}{\mathrm{d} x}$,

where the distance between sampling stations $\mathrm{d} x$ was $540 \mathrm{~m}$ and $\bar{h}$ was the mean water depth along $\mathrm{d} x$. Nutrient concentrations at $\mathrm{CR}$ and $\mathrm{SG}$ are represented by $C_{\mathrm{CR}}$ and $C_{\mathrm{SG}}$, respectively; $\bar{C}$ is the mean of $C_{\mathrm{CR}}$ and $C_{\mathrm{SG}}$ at a given time step (Genin et al., 2002). Positive values of $J_{\text {net }}$ represent net benthic nutrient uptake and negative $J_{\text {net }}$ indicates net release of nutrients to the water column; these fluxes are the net result of all biogeochemical processes occurring between SG and $\mathrm{CR}$, and thus represent fluxes from a combination of seagrass and coral reef communities. The "local" benthic flux (i.e., nutrient uptake or release occurring in the reference frame of the sampling stations) is represented by the first right-side term of Eq. (2) and was estimated at hourly intervals when water sampling occurred. The second term of Eq. (2) represents the "advective" flux (i.e., nutrient uptake or release during transit between sampling stations). Transit time between stations changed throughout the tidal cycle and could be on the order of hours during periods of slow flow $\left(<5 \mathrm{~cm} \mathrm{~s}^{-1}\right)$. To better represent the advective component, advective fluxes were calculated at every point where nutrient concentrations were available and were then bin-averaged over a time interval that approximated the transit time. These estimates were then linearly interpolated to times where local estimates existed.

\subsection{Uptake rates at the limits of mass transfer}

For comparison with the field observations, the theoretical uptake rates of DIN and DIP at the limits of mass transfer 
( $J_{\text {MTL }}$ ) were calculated for each of the measurements of $J_{\text {net }}$ above. Assuming nutrient concentrations at the tissue surface of benthic organisms were near zero, $J_{\text {MTL was estimated }}$ along the study transect (from SG to CR) as follows (Falter et al., 2004):

$J_{\mathrm{MTL}}=S \bar{C}$,

where $S$ is the mass-transfer velocity (in $\mathrm{m} \mathrm{d}^{-1}$ ). Estimates of $J_{\text {MTL }}$ and $S$ were made for $\mathrm{NO}_{x}, \mathrm{NH}_{4}^{+}$, and DIP and were averaged over the same time intervals as $J_{\text {net }}$. Mass-transfer velocity $S$ was estimated as follows (Falter et al., 2004):

$S=u_{x} C_{\mathrm{D}}^{0.5} /\left(R e_{k}^{0.2} S c^{0.6}\right)$

where $C_{\mathrm{D}}$ is the drag coefficient, $R e_{k}$ is the roughness Reynolds number, and $S c$ is the Schmidt number. Masstransfer velocity is a function of flow speed and is indirectly related to water depth through the drag coefficient; the magnitude of $S$ depends on the diffusivity of the nutrient species of interest (through the Schmidt number) yet is unrelated to nutrient concentration (see below). The Schmidt number is defined as the kinematic viscosity $v$ divided by the diffusion coefficient $D$ of the nutrient species, which were 19.05, 19.80 , and $7.00 \times 10^{-6} \mathrm{~cm}^{2} \mathrm{~s}^{-1}$ for $\mathrm{NO}_{x}, \mathrm{NH}_{4}^{+}$, and $\mathrm{PO}_{4}^{3-}$, respectively (Li and Gregory, 1974). The drag coefficient $C_{\mathrm{D}}$ increases dramatically as reef water depth decreases (Lentz et al., 2017) and was estimated from an empirical relationship between $h$ and the mean height of reef ridges $h_{\mathrm{r}}$ as follows (McDonald et al., 2006):

$C_{\mathrm{D}}=1.01\left(h / h_{\mathrm{r}}\right)^{-2.77}+0.01$,

where $h_{\mathrm{r}}$ was determined by measuring the mean height (vertical distance between the crest and trough of a reef ridge) of all ridges along a $50 \mathrm{~m}$ transect. The roughness Reynolds number $R e_{k}$ is defined as follows:

$R e_{k}=u_{*} k_{\mathrm{s}} / v$,

where $k_{\mathrm{s}}$, a hydraulic roughness length scale, was $0.5 \mathrm{~m}$ (Lowe et al., 2015) and the shear velocity $u_{*}$ is a function of bottom shear stress $\tau_{\mathrm{b}}$ and seawater density $\rho$ as follows:

$u_{*} \equiv \sqrt{\tau_{\mathrm{b}} / \rho}=u_{x} \sqrt{C_{\mathrm{D}} / 2}$.

Estimates of maximum potential nutrient release ( $\left.J_{\text {release }}\right)$ represent the flux of $\mathrm{NO}_{x}, \mathrm{NH}_{4}^{+}$, and DIP necessary to match the observed $J_{\text {net }}$ assuming uptake occurred at mass-transferlimited rates and were estimated as follows (Wyatt et al., 2012):

$J_{\text {release }}=J_{\text {net }}-J_{\mathrm{MTL}}$,

for each of the intervals over which $J_{\text {net }}$ was calculated.

Large changes in water depth, flow speed, and nutrient concentration occurred during each tidal cycle, yet measurements of $J_{\text {net }}$ could only be made during ebb tide (generally $6-12 \mathrm{~h}$ after onset of reef flooding). In order to understand how the range of flow speeds experienced by this reef platform could influence maximum potential nutrient uptake rates, we calculated $J_{\text {MTL }}$ continuously over a full $\sim 15 \mathrm{~d}$ spring-neap cycle at individual stations SG and CR. Flow speed measurements from an April 2014 experiment were used, which included an acoustic Doppler profiler (ADP) and acoustic Doppler velocimeter (ADV) located at SG and CR, respectively; as discussed previously, flows on Tallon reef can be predicted based on water depth and tidal phase (Lowe et al., 2015), so measurements from April would be representative of flows during October and February experiments. Calculations were made as above (Eqs. 3-7) with the exception of using $u$ instead of $u_{x}$ (Eqs. 4, 7), as we are now estimating fluxes over the full tidal cycle rather than only the roughly unidirectional ebb tide portion. Tidal phase-averaged concentrations of $\mathrm{NO}_{x}, \mathrm{NH}_{4}^{+}$, and DIP were approximated for both sites (CR and $\mathrm{SG}$ ) and field experiments (October and February) using measured concentrations (Fig. 3), where available. As it was not possible to collect water samples during peak ebb tide (due to hazardous conditions), nutrient concentrations in offshore waters (Table 1) were assumed to be representative of concentrations on the reef platform during those times.

In a strongly tide-dominated system such as Tallon reef, each tidal cycle "refills" the reef by flushing it with fresh oceanic water. In order to conceptualize the net biogeochemical fluxes that occur over this cycle, we used tidal cycle averages. Tidal cycle averages of mass-transfer velocities $\left(S_{\mathrm{cyc}}\right)$ and mass-transfer-limited nutrient flux $\left(J_{\text {cyc }}\right)$ were calculated as the mean of all $S$ and $J_{\mathrm{MTL}}$, respectively, occurring within an individual semidiurnal tidal cycle beginning when water flooded the reef platform.

Uncertainties in estimates of $S, J_{\text {net }}$, and $J_{\text {MTL }}$ were estimated by propagating standard deviations using Monte Carlo simulation (10 000 iterations). Error terms for hydrodynamic variables were derived from bin-averaged data (Lehrter and Cebrian, 2010) and were $0.01 \mathrm{~m}$ for $h, 0.03 \mathrm{~m} \mathrm{~s}^{-1}$ for $u$, $0.05 \mu \mathrm{M}$ for concentrations of $\mathrm{NO}_{x}$ and $\mathrm{NH}_{4}^{+}, 0.01 \mu \mathrm{M}$ for DIP, $1.0 \mu \mathrm{M}$ for DON. Tidal phase-averaged concentrations of $\mathrm{NO}_{x}$ and DIP used in $J_{\text {MTL }}$ estimates were assigned standard deviations of 0.5 and $0.05 \mu \mathrm{M}$, respectively.

\section{Results}

\subsection{Nutrient concentrations and measured fluxes}

Characteristics of offshore water (temperature, salinity, and nutrient concentrations) showed some differences between dry and wet season field experiments. Water temperature was $\sim 2{ }^{\circ} \mathrm{C}$ warmer during the wet season in February, and levels of DIN were elevated, with $\mathrm{NO}_{x}$ concentrations approximately double those measured during the dry season in October (Table 1). Salinity and concentrations of DIP and DON were similar between seasons. Reef platform nutrient concentrations were similar to offshore concentrations during 


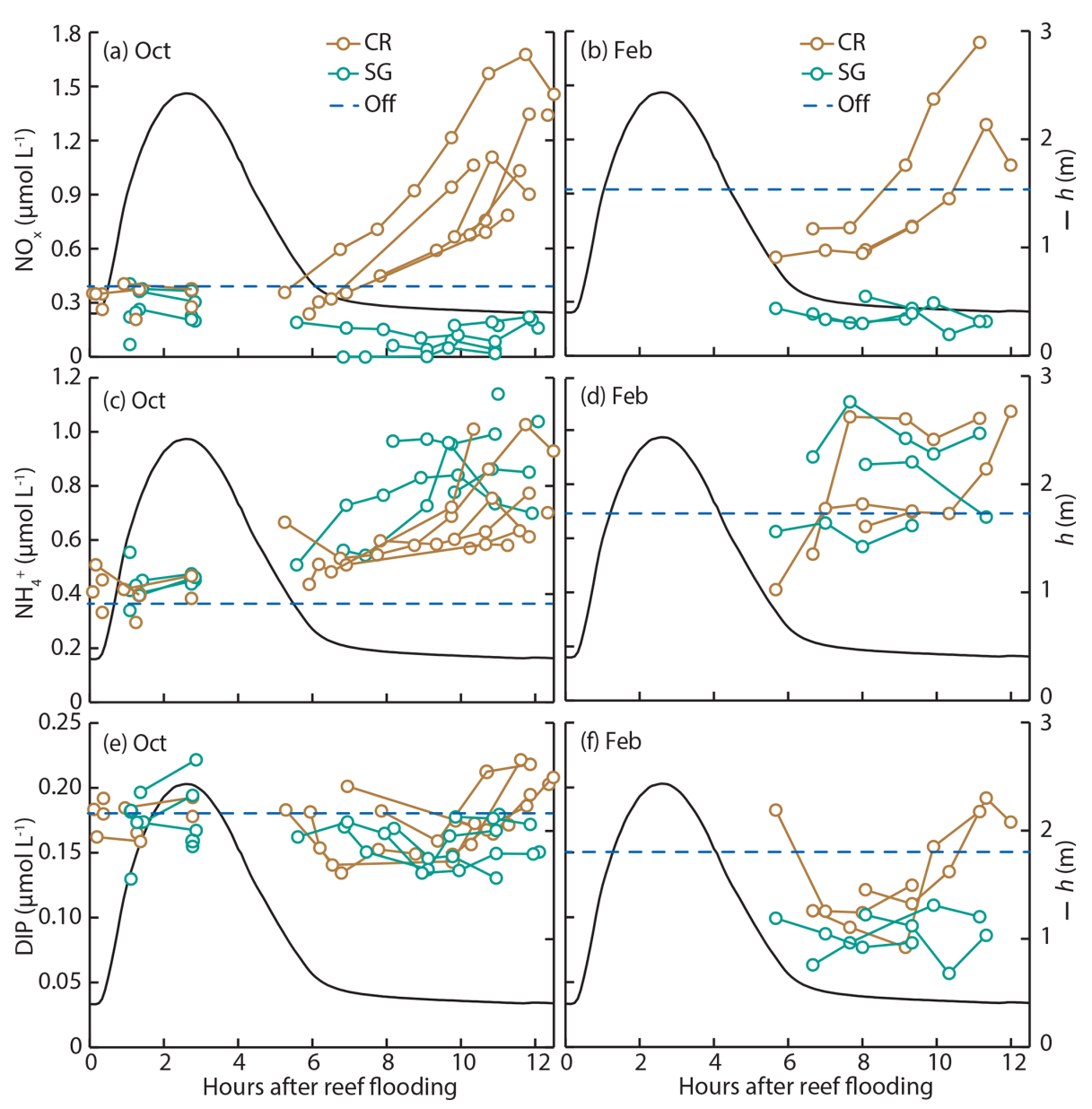

Figure 3. Measurements of (a, b) nitrate $\left(\mathrm{NO}_{x}\right)$, $(\mathbf{c}, \mathbf{d})$ ammonium $\left(\mathrm{NH}_{4}^{+}\right)$, and $(\mathbf{e}, \mathbf{f})$ dissolved inorganic phosphorus (DIP) from water samples during October $(\mathbf{a}, \mathbf{c}, \mathbf{e})$ and February $(\mathbf{b}, \mathbf{d}, \mathbf{f})$ field experiments. Samples were taken at two reef stations; CR- and SG-dominated zones and mean offshore nutrient concentrations are shown (dashed blue line). Tidal phase-averaged water depth $h$ is also shown (black line).

flood tide and the start of ebb tide $(\sim 3-6 \mathrm{~h}$ after reef flooding, Fig. 3); during the remaining $6 \mathrm{~h}$ of ebb tide, the concentrations of DIN changed dramatically depending on the reef zone (benthic community type). In the case of $\mathrm{NO}_{x}$, concentrations decreased in the seagrass zone (SG) but increased in the coral zone (CR) by up to 5 times compared to offshore levels (Fig. 3a, b). Increases in $\mathrm{NH}_{4}^{+}$occurred at both SG and CR during ebb tide (Fig. 3c, d), while DIP was generally lower than offshore concentrations but tended to increase at CR during the final few hours of ebb tide (Fig. 3e, f).

Fluxes of DIN and DIP estimated using the CoVo technique were generally negative, indicating a net efflux (release) of nutrients from the benthos to the water column. This was especially true for $\mathrm{NO}_{x}$, where net nutrient release $\left(J_{\text {net }}<0\right)$ reached $5 \mathrm{mmol} \mathrm{m}^{-2} \mathrm{~d}^{-1}$ (Fig. 4a), and net uptake $\left(J_{\text {net }}>0\right)$ was not observed during any point in either field experiment. Fluxes of $\mathrm{NH}_{4}^{+}$and DIP varied between net uptake and release (Fig. $4 \mathrm{~b}, \mathrm{c}$ ), and $J_{\text {net }}$ for DIP tended to transition from net uptake to net release over the duration of ebb tide. There were no substantial differences in overall mean $J_{\text {net }}$ of dissolved inorganic nutrients between October and February field experiments (Table 2). Fluxes of DON did differ between seasons; $J_{\text {net }}$ varied between net uptake and net release during October (Fig. 4d) although mean $J_{\text {net }}$ was negligible (Table 2). During February, $J_{\text {net }}$ of DON transitioned from net uptake to net release over the ebb tide (Fig. 4d) but showed a large uptake on average (Table 2).

\subsection{Mass-transfer velocity and nutrient uptake}

For simplicity, only values of $S$ for $\mathrm{NO}_{x}$ are shown, as the values of other species $\left(\mathrm{NH}_{4}^{+}\right.$, DIP) differ only in magnitude by a constant factor (due to diffusivity). Although temperature influences $S$ through viscosity, changes in temperature on the reef platform had a negligible effect on $S$ $(<0.01 \%)$ compared to reef hydrodynamics. The tidal phaseaverages of $S$ on the reef platform (Fig. 5) demonstrate the strong influence of flow speed and water depth on $S$. Masstransfer velocities rose sharply during the peak flood and ebb periods (0-1.5 and $4-6 \mathrm{~h}$ after reef flooding, respectively). 

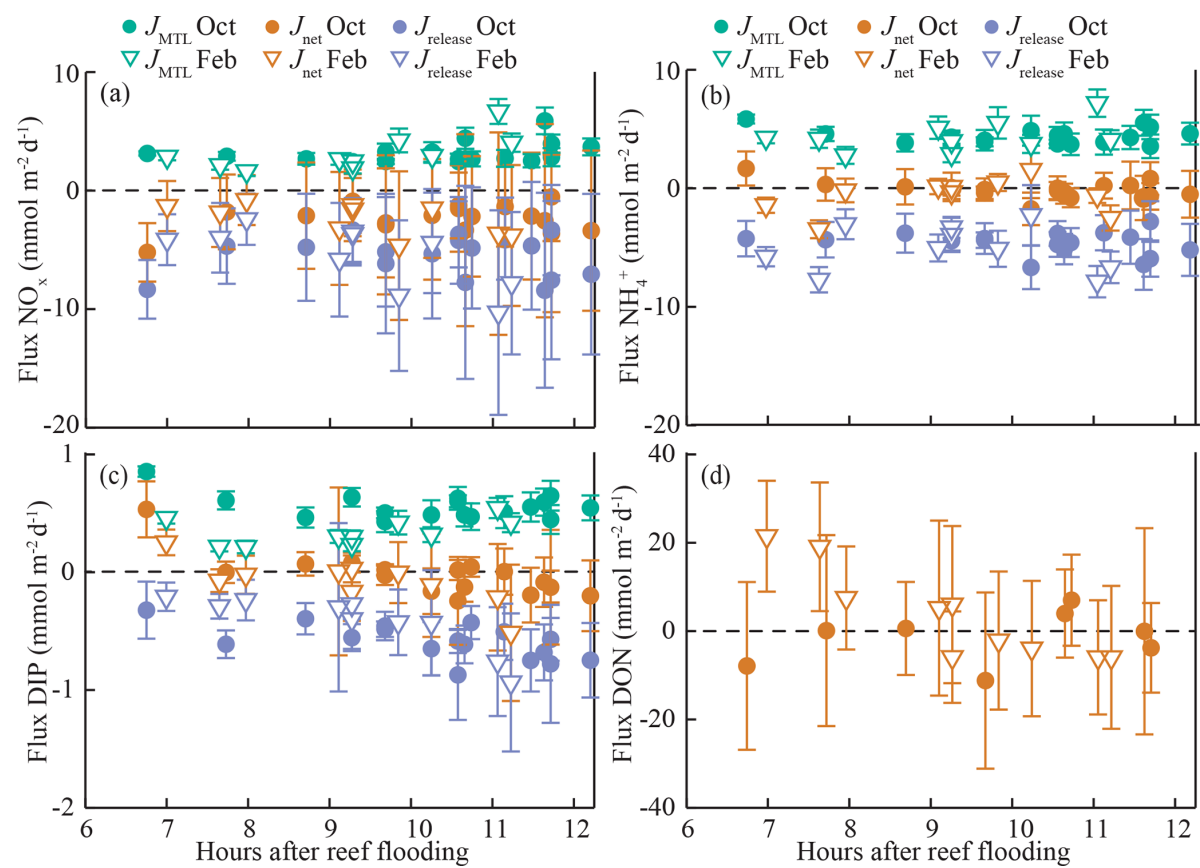

Figure 4. Fluxes ( \pm standard deviation) of (a) nitrate $\left(\mathrm{NO}_{x}\right)$, (b) ammonium $\left(\mathrm{NH}_{4}^{+}\right),(\mathbf{c})$ dissolved inorganic phosphorus $(\mathrm{DIP})$, and (d) dissolved organic nitrogen (DON) along the study transect during both field experiments. Net benthic fluxes ( $\left.J_{\text {net }}\right)$ were estimated using the CoVo approach, while mass-transfer-limited uptake ( $J_{\text {MTL }}$ ) was calculated (Eq. 3) from reef platform flow and nutrient concentrations, and nutrient release $\left(J_{\text {release }}\right)$ was estimated from net and MTL fluxes.

Table 2. Mean (italics indicate standard error) net fluxes (in mmol m $\mathrm{m}^{-2} \mathrm{~d}^{-1}$ ) of nutrients determined by the CoVo approach during the October and February field experiments. Nutrient species include nitrate and nitrite $\left(\mathrm{NO}_{x}\right)$, ammonium $\left(\mathrm{NH}_{4}^{+}\right)$, dissolved inorganic phosphorus (DIP), and dissolved organic nitrogen $(\mathrm{DON})$. Mean net $\left(J_{\text {net }}\right)$, mass-transfer-limited $\left(J_{\mathrm{MTL}}\right)$, and release $\left(J_{\text {release }}\right)$ fluxes are from samples taken during the final $6 \mathrm{~h}$ of ebb tide and do not represent fluxes at all phases of the semidiurnal tidal cycle.

\begin{tabular}{llrr}
\hline & & Oct 2013 & Feb 2014 \\
\hline $\mathrm{NO}_{x}$ & $J_{\text {net }}$ & $-2.3(0.29)$ & $-2.4(0.47)$ \\
& $J_{\text {MTL }}$ & $3.3(0.04)$ & $3.1(0.20)$ \\
& $J_{\text {release }}$ & $-5.5(0.30)$ & $-5.5(0.47)$ \\
\hline \multirow{2}{*}{$\mathrm{NH}_{4}^{+}$} & $J_{\text {net }}$ & $-0.06(0.07)$ & $-0.6(0.11)$ \\
& $J_{\text {MTL }}$ & $4.6(0.05)$ & $4.5(0.09)$ \\
& $J_{\text {release }}$ & $-4.6(0.09)$ & $-5.0(0.14)$ \\
\hline \multirow{2}{*}{ DIP } & $J_{\text {net }}$ & $-0.03(0.013)$ & $-0.08(0.038)$ \\
& $J_{\text {MTL }}$ & $0.56(0.006)$ & $0.35(0.007)$ \\
& $J_{\text {release }}$ & $-0.59(0.014)$ & $-0.43(0.039)$ \\
\hline \multirow{2}{*}{ DON } & $J_{\text {net }}$ & $-1.6(2.07)$ & $3.4(1.50)$ \\
\hline
\end{tabular}

The largest $S$ each tidal cycle occurred at the beginning of flood tide, characterized by high flow speeds $\left(\sim 0.5 \mathrm{~m} \mathrm{~s}^{-1}\right)$ and minimum water depths $(\sim 0.4 \mathrm{~m})$ on the reef platform (Fig. 2); values of $S$ during flood tide were $\sim 30 \%$ greater at CR compared to SG, which was due to the larger flow speeds and slightly shallower $(10 \mathrm{~cm})$ water depths that occurred near the reef crest. The lowest $S$ for each tidal cycle (Fig. 5) occurred at high tide when flow speeds became negligible and reef water depths were comparatively large $(\sim 2.5 \mathrm{~m})$. Values of $S$ were relatively small $\left(\sim 5 \mathrm{~m} \mathrm{~d}^{-1}\right.$ for $\mathrm{NO}_{x}$ ) later in the ebb tide (8-12 $\mathrm{h}$ after reef flooding) and were similar between SG and CR. As $S$ was estimated over a full spring-neap tidal cycle, the ranges of values shown (Fig. 5) are from the most (spring) and least (neap) energetic tidal cycles, which cause $S$ to vary by a factor of $<4$.

The mass-transfer-limited nutrient fluxes $J_{\mathrm{MTL}}$ were a function of both $S$ and the local nutrient concentrations (Eq. 3). Fluxes showed variability over the tidal cycle associated with $S$ but also showed prominent differences between benthic communities and seasons related to nutrient concentrations. Elevated $\mathrm{NO}_{x}$ concentrations at $\mathrm{CR}$ (Fig. 3a, b) resulted in rising $J_{\mathrm{MTL}}$ during the final $6 \mathrm{~h}$ of ebb tide, while low $\mathrm{NO}_{x}$ concentrations at $\mathrm{SG}$ resulted in low $J_{\mathrm{MTL}}$, especially during ebb tide (Fig. 6). Similar concentrations of DIP (Fig. 3e, f) between sites resulted in similar $J_{\mathrm{MTL}}$ between CR and SG (Fig. 6c, d). Seasonal changes in offshore nutrient concentrations, particularly for $\mathrm{NO}_{x}$, have the potential 

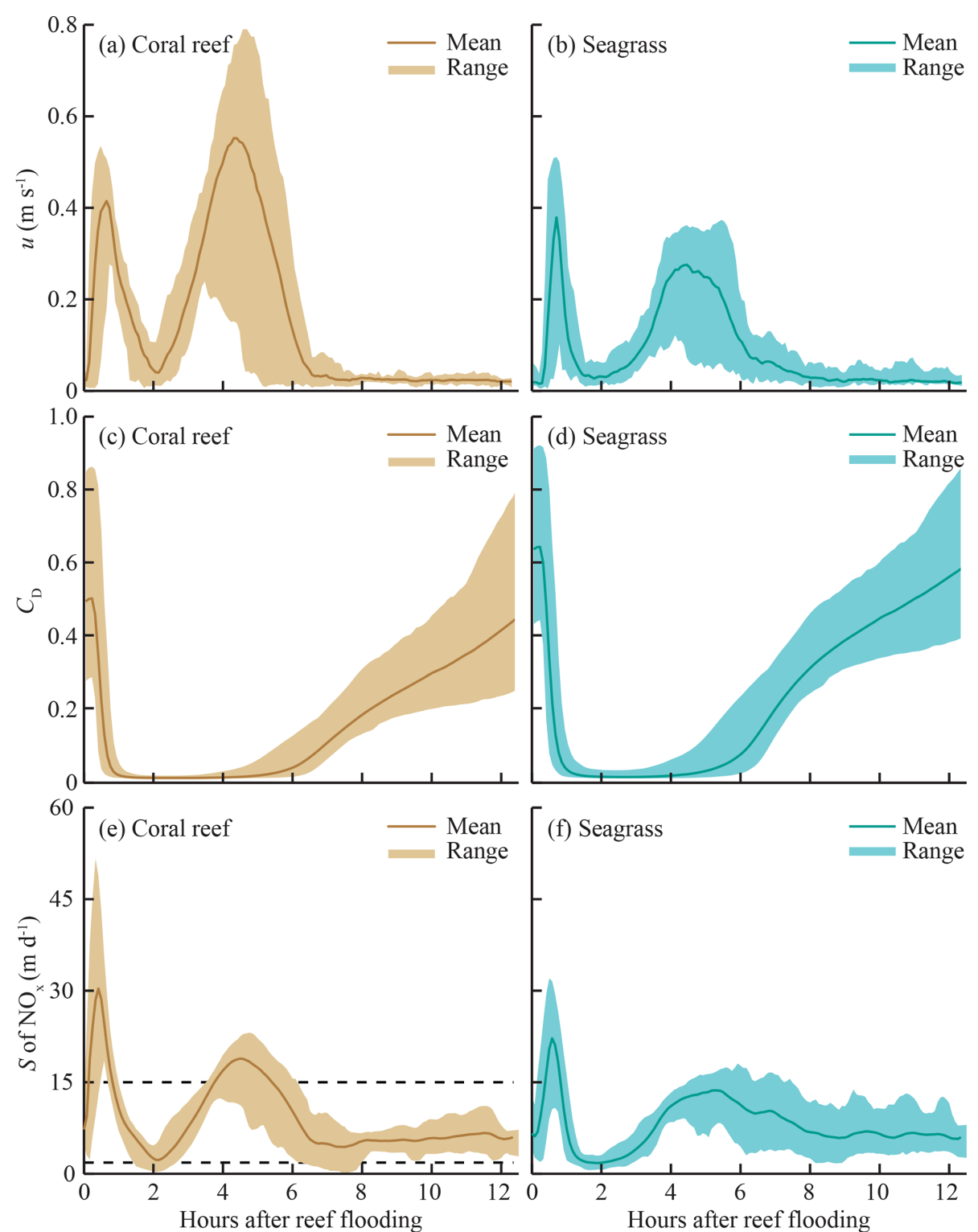

Figure 5. Tidal phase-averages of flow speed $u$, drag coefficient $C_{\mathrm{D}}$, and mass-transfer velocity $S$ for nitrate $\left(\mathrm{NO}_{x}\right)$ in coral- and seagrassdominated zones. Phase-averages are the mean of all measurements occurring at the same point in the tidal cycle (e.g., mean of all $S$ at high tide), and the range represents conditions during spring and neap tidal cycles. Hydrodynamic data are from April 2014. Dashed lines in panel (e) indicate upper and lower limits of $S$ measured from previous studies of reef communities reviewed by Atkinson and Falter (2003).

to enhance nutrient uptake rates. Elevated offshore $\mathrm{NO}_{x}$ during February (Table 1) resulted in a doubling of estimated $J_{\text {MTL }}$ during flood and high tide portions of each tidal cycle, compared to October (Fig. 6a, b). Seasonal differences in $J_{\text {MTL }}$ were also found for DIP, where elevated fluxes occurred during October (compared to February) due to higher DIP concentration in the dry season (Table 1, Fig. 6c, d). The maximum potential release of DIN and DIP to the water column, assuming uptake was mass-transfer-limited $\left(J_{\text {release }}\right.$, Eq. 8), was calculated for every instance of measured $J_{\text {net }}$ (Fig. 4). In the case of $\mathrm{NO}_{x}, J_{\text {release }}$ was roughly double $J_{\text {net }}$ (Fig. 4a), due to the large net $\mathrm{NO}_{x}$ release measured on the reef platform. Whereas for $\mathrm{NH}_{4}^{+}$and DIP, $J_{\text {release }}$ was on the order of $J_{\mathrm{MTL}}$, due to negligible values of $J_{\text {net }}$ (Fig. 4b, c). Overall mean rates of $J_{\mathrm{MTL}}$ and $J_{\text {release }}$ for DIN did not show seasonal differences (Table 2), which was likely a function of these estimates only occurring during a portion (ebb) of the tidal cycle.

When $S$ was averaged over individual semidiurnal tidal cycles (e.g., mean of all $S$ within a tidal cycle, beginning with reef flooding), the difference between SG and CR was only $\sim 1 \mathrm{~m} \mathrm{~d}^{-1}$ (Fig. 7). Mass-transfer velocities for $\mathrm{NO}_{x}$ and $\mathrm{NH}_{4}^{+}$were of similar magnitude over the tidal cycle, while those for DIP were $\sim 50 \%$ lower (Fig. 7); this was a function 

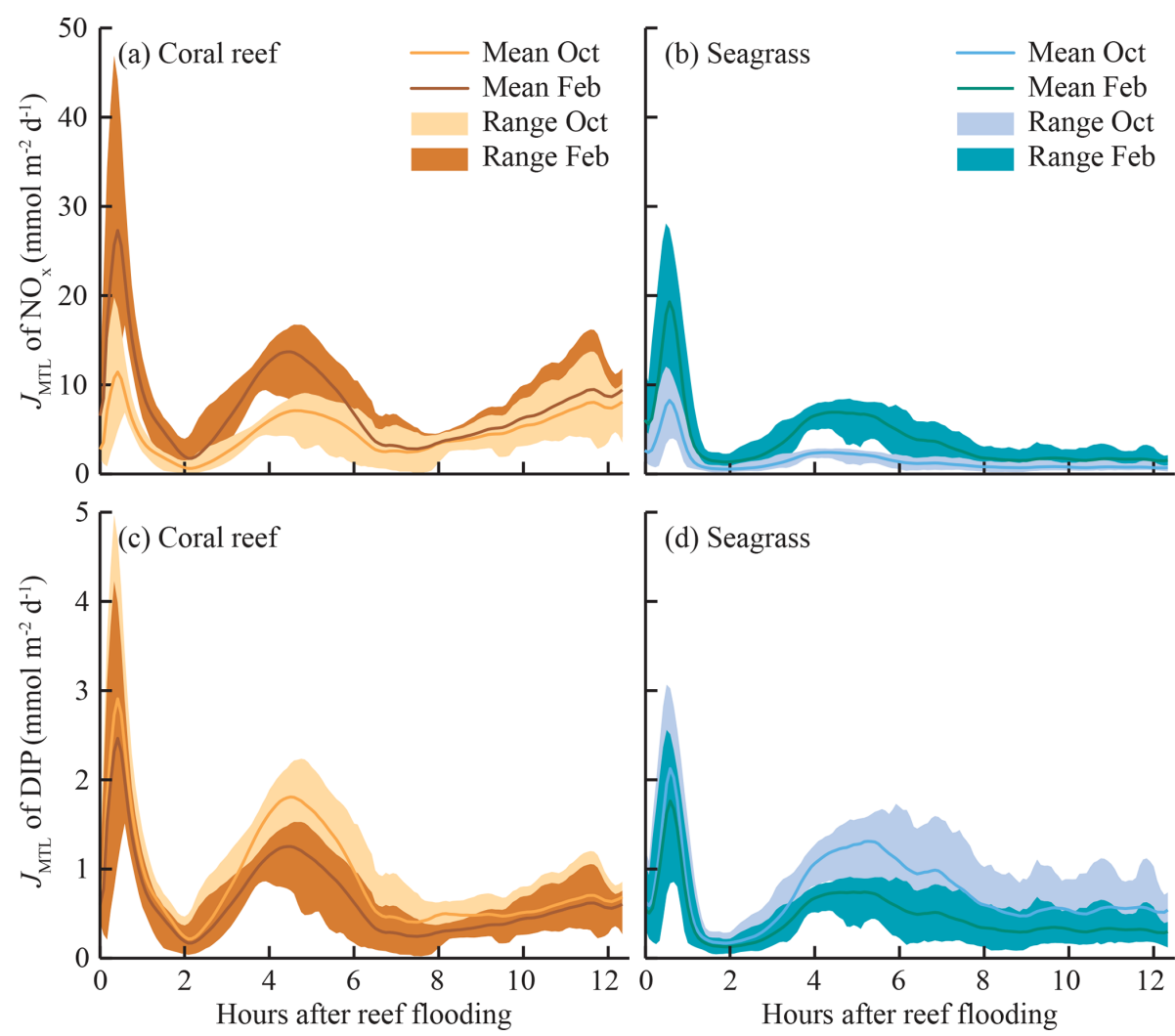

Figure 6. Tidal phase-averaged mass-transfer-limited uptake rates of $J_{\mathrm{MTL}}$ for (a, b) $\mathrm{NO}_{x}$ and (c, d) DIP in both coral- and seagrassdominated zones over a full spring-neap cycle. Phase-averages are the mean of all measurements occurring at the same point in the tidal cycle (i.e., mean of all $J_{\mathrm{MTL}}$ at high tide). Shaded areas of $J_{\mathrm{MTL}}$ indicate the range where maximum values approximate uptake during spring tides and minimum values during neap tides. Estimates of $J_{\mathrm{MTL}}$ were calculated using tidal phase-averaged nutrient concentrations from October and February field experiments (Fig. 3) and mass-transfer velocity $S$ (Fig. 5e, f).

of the diffusivity of each of these solutes ( $\mathrm{Li}$ and Gregory, 1974). When $J_{\mathrm{MTL}}$ was similarly averaged over individual tidal cycles (Fig. 8), community and seasonal differences in $J_{\text {MTL }}$ described previously (Fig. 6) were prominent. Uptake of $\mathrm{NO}_{x}$ showed the greatest differences between seasons and sites, with uptakes rates during the wet season greater than dry season rates by a factor of $\sim 2$. Similarly, estimates of DIP uptake were slightly enhanced during the dry season compared to wet season rates, while uptake of $\mathrm{NH}_{4}^{+}$was similar between seasons and sites (Fig. 8).

\section{Discussion}

\subsection{Oceanic nutrient supply}

The measurements of offshore nutrient concentrations presented in Table 1 are among the first published for the Kimberley region (Jones et al., 2014) and are the only (to our knowledge) published record that includes measurements during the wet season. Concentrations of dissolved nutrients $\left(\mathrm{NO}_{x}, \mathrm{NH}_{4}^{+}\right.$, DIP, and DON) were at the upper end of typical values in coral reef waters worldwide, especially in the case of DON, which far exceeded the $<5 \mu \mathrm{M}$ common in reef waters (Atkinson and Falter, 2003). Measurements from the coastal Kimberley (Table 1) also exceeded long-term mean values from inshore waters of the Great Barrier Reef (GBR) during both the wet and dry seasons (Furnas et al., 2005; Schaffelke et al., 2012). The Kimberley region shares similar rainfall patterns, tidal ranges, and low levels of catchment alteration with the northern GBR (at a similar latitude to the Kimberley), yet concentrations of DIN and DIP measured in this study were an order of magnitude greater than those from the wet tropics (Furnas et al., 2005; Schaffelke et al., 2012). These observations, coupled with elevated concentrations of chlorophyll $a$ and particulate nutrients (Gruber et al., 2018) relative to "typical" oligotrophic reef waters, suggest that some coastal Kimberley reefs may experience naturally mesotrophic conditions.

Wet season terrestrial discharge events deliver sediment and nutrients to coastal waters of northern Australia (Brodie et al., 2010; Devlin and Schaffelke, 2009; Schroeder et al., 2012). Offshore concentrations of $\mathrm{NO}_{x}$ and $\mathrm{NH}_{4}^{+}$measured in our study approximately doubled during the February field experiment compared to October, whereas DIP and DON 


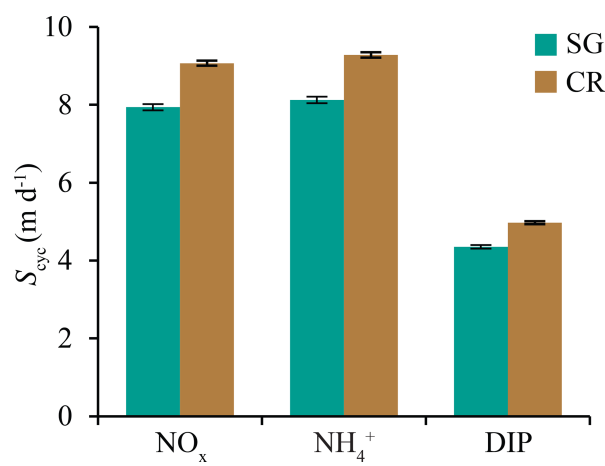

Figure 7. Means ( \pm standard deviation) of mass-transfer velocity $S$ for all individual semidiurnal tidal cycles $(n=23)$ for nitrate $\left(\mathrm{NO}_{x}\right)$, ammonium $\left(\mathrm{NH}_{4}^{+}\right)$, and dissolved inorganic phosphorus (DIP). Values are from SG- and CR-dominated communities.

were similar between seasons (Table 1). Whether this increase is due to river discharge or coastal oceanographic processes is not presently clear in the Kimberley region and warrants future study. Ratios of offshore DIN : DIP were 4.3 and 10.7 in October and February, respectively (Table 1), with the value during October similar to the DIN : DIP ratio of $\sim 3: 1$ previously found in coastal Kimberley waters during the dry season (Jones et al., 2014). These values are below the Redfield ratio (16:1), suggesting that pelagic production may be $\mathrm{N}$-limited. This is common for reef waters generally, although long-term averages of inshore GBR waters are generally $<3: 1$ even during the wet season (Furnas et al., 2005; McKinnon et al., 2013; Schaffelke et al., 2012). This suggests that N-limitation may be less severe in the Kimberley than in GBR waters, particularly during the wet season.

\subsection{Rates and sources of benthic release of DIN and DIP}

Benthic nutrient fluxes measured using the control volume technique $\left(J_{\text {net }}\right)$ showed net release of $\mathrm{NO}_{x}$ on Tallon (Fig. 4a), while $\mathrm{NH}_{4}^{+}$and DIP fluxes varied between uptake and release (Fig. $4 \mathrm{~b}, \mathrm{c}$ ) but were negligible overall during the ebb tide (Table 2). Previous studies of reef nutrient fluxes in flumes or other controlled environments have generally shown uptake approaching the limits of mass transfer for $\mathrm{NH}_{4}^{+}$(e.g., Atkinson et al., 1994; Cornelisen and Thomas, 2009; Larned and Atkinson, 1997; Thomas and Atkinson, 1997), DIP (reviewed in Cuet et al., 2011b), and, less frequently, for $\mathrm{NO}_{x}$ (e.g., Baird et al., 2004); these controlled environments lack some of the confounding processes present in natural reef communities. Yet net release of nutrients (especially $\mathrm{NO}_{x}$ ) clearly occurs in situ as concentrations on many reefs exceed those offshore (e.g., Hatcher and Frith, 1985; Leichter et al., 2013; Rasheed et al., 2002), and release rates up to $20 \mathrm{mmol} \mathrm{NO}_{x} \mathrm{~m}^{-2} \mathrm{~d}^{-1}, 12 \mathrm{mmol} \mathrm{NH}_{4}^{+} \mathrm{m}^{-2} \mathrm{~d}^{-1}$, and $2 \mathrm{mmolDIP} \mathrm{m}^{-2} \mathrm{~d}^{-1}$ have been measured with in situ studies (Miyajima et al., 2007a, b; Silverman et al., 2012;
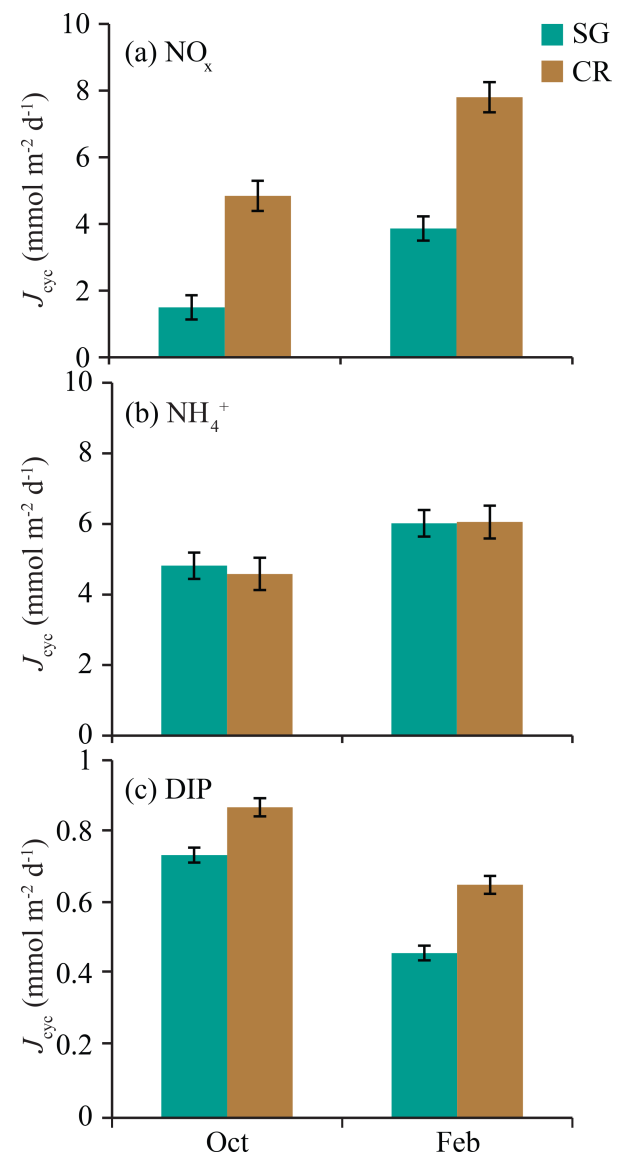

Figure 8. Means ( \pm standard deviation) of mass-transfer-limited uptake $J_{\text {MTL }}$ for all individual semidiurnal tidal cycles $(n=23)$ for (a) nitrate $\left(\mathrm{NO}_{x}\right)$, (b) ammonium $\left(\mathrm{NH}_{4}^{+}\right)$, and (c) dissolved inorganic phosphorus (DIP). Values are from SG- and CR-dominated communities during October and February field experiments.

Wyatt et al., 2012). We have not considered nitrogen inputs from other sources such as $\mathrm{N}_{2}$ fixation (Cardini et al., 2014) or reef porewater advection during ebb tide (Santos et al., 2011), which may result in an overestimation of DIN release on Tallon. However, given that $\mathrm{NO}_{x}$ concentrations generally approach detection limits in reef porewater (Sansone et al., 1990; Tribble et al., 1990) and $\mathrm{N}_{2}$ fixation adds to the $\mathrm{NH}_{4}^{+}$pool, it seems unlikely that either of these processes dominate the observed nutrient fluxes.

If we assume that the fluxes discussed above $\left(J_{\text {net }}\right)$ simultaneously occur with uptake of DIN and DIP near the limits of mass transfer, this gives a gross release $\left(J_{\text {release }}\right)$ of $\sim 10 \mathrm{mmol} \mathrm{N} \mathrm{m}^{-2} \mathrm{~d}^{-1}$ and $\sim 0.5 \mathrm{mmol} \mathrm{P} \mathrm{m}^{-2} \mathrm{~d}^{-1}$ (Table 2). Previous work has attributed inorganic nutrient release to remineralization of particulate material by benthic filter feeders (Ribes et al., 2005; Wyatt et al., 2012) and detritivores (Silverman et al., 2012), which can graze PON on the order of DIN release rates, as well as nitrification by sponge communities (Southwell et al., 2008). In the case of Tallon reef, uptake of phytoplankton $(0.95 \mathrm{mmolN}$ and 
$0.20 \mathrm{mmol} \mathrm{P} \mathrm{m}^{-2} \mathrm{~d}^{-1}$ ) (Gruber et al., 2018) is on the order of $J_{\text {release }}$ in the case of $\mathrm{P}$ but is much smaller than $J_{\text {release }}$ of N. Large particles (such as entire fronds of macroalgae) are rare but can form a major component of the particulate organic pool on some reefs (Alldredge et al., 2013); remineralization of similar material (rather than small particles like phytoplankton) may be the source of the observed DIN release on Tallon. Finally, fluxes of DON on the order of $J_{\text {net }}$ were measured on Tallon, with net uptake occurring during the February experiment (Fig. 4d). The dynamics of DON in reef systems have been addressed in a few studies (e.g., Haas and Wild, 2010; Thibodeau et al., 2013; Ziegler and Benner, 1999), and there is some evidence that reef organisms including corals (Ferrier, 1991), sponges (Rix et al., 2017), and seagrasses (Vonk et al., 2008) can directly utilize DON. In summary, gross release of DIP may be derived from phytoplankton uptake on Tallon reef, but released DIN exceeds phytoplankton inputs and is likely derived from additional sources including remineralization of large particles and DON.

\subsection{Tidal and seasonal forcing of mass-transfer-limited fluxes}

Few estimates of nutrient uptake rate $S$ exist for in situ reef communities; the majority of previous estimates come from controlled flume experiments and are in the range of 2$15 \mathrm{~m} \mathrm{~d}^{-1}$ (reviewed in Atkinson and Falter, 2003). Uptake rates are strongly dependent on flow and roughness characteristics (Falter et al., 2016), and in wave-dominated systems $S$ can vary by an order of magnitude across the reef (e.g., from $25 \mathrm{~m} \mathrm{~d}^{-1}$ on the fore-reef to $5 \mathrm{~m} \mathrm{~d}^{-1}$ in the back-reef), as bottom stress from wave forcing declines (Wyatt et al., 2012; Zhang et al., 2011). In wave-dominated systems, $S$ would be expected to be reasonably consistent while offshore wave forcing remain similar (e.g., at scales of days-weeks). Estimates of $S$ from Tallon reef show uptake rates varying rapidly on the scale of hours or even minutes; for instance, uptake rates for $\mathrm{NO}_{x}$ decreased by an order of magnitude $\left(\sim 30-3 \mathrm{~m} \mathrm{~d}^{-1}\right)$ over the period of an hour during flood tide (Fig. 5e). When averaged over longer timescales (i.e., over individual semidiurnal tidal cycles), estimates of $S$ for DIN and DIP ( $\sim 9$ and $\sim 5 \mathrm{~m} \mathrm{~d}^{-1}$, respectively) were similar to the mean of those measured in previous studies and only differed slightly between seagrass and coral reef zones (Fig. 7). Tallon reef platform experiences flows and water depths particular to its geometry and position relative to mean sea level; therefore, $S$ (and accordingly nutrient uptake) will vary in other tide-dominated reef communities as a function of these factors.

Estimates of mass-transfer-limited uptake of DIN and DIP varied over a tidal cycle with $S$ but also showed differences in uptake with reef zone and season (Fig. 6). Reef zones were similar in DIP uptake rates, but rising concentrations of $\mathrm{NO}_{x}$ in the coral zone during ebb tide caused estimates of $J_{\mathrm{MTL}}$ to increase compared to the seagrass zone (Fig. 6a, b). Previous work on Tallon reef has shown that the coral zone is $\sim 20 \%$ more productive than the seagrass zone (Gruber et al., 2017), which may be related to this difference in potential nitrate fluxes. Concentrations of $\mathrm{NO}_{x}$ and $\mathrm{NH}_{4}^{+}$were elevated in the wet season, while DIP declined compared to the dry season (Table 1); these seasonal differences were evident in the mass-transfer-limited nutrient fluxes even when integrated over individual semidiurnal tidal cycles (Fig. 8). Ratios of DIN : DIP mass-transfer-limited uptake during October were 8.6 and 10.8 for seagrass and coral zones, respectively (Fig. 8). These ratios are well below the tissue $\mathrm{N}: \mathrm{P}$ ratio of $30: 1$ typical of reef primary producers (Atkinson and Smith, 1983) and suggest that producers on Tallon reef may be strongly N-limited (at least during the dry season). This is supported by low $\mathrm{N}: \mathrm{P}$ ratios $(14: 1)$ measured in Thalassia leaf tissue from Tallon reef during October (Cayabyab, unpublished data). During February, ratios of DIN : DIP masstransfer-limited uptake were 21.5 and 21.3 for seagrass and macroalgal zones, respectively (Fig. 8), which suggests that $\mathrm{N}$-limitation may be somewhat alleviated due to increases in oceanic DIN during the wet season.

\subsection{Comparison of wave and tidal forcing}

This study suggests several important differences between wave- and tide-dominated reef biogeochemistry, which are controlled by the hydrodynamic regime. Firstly, the "source" of a water parcel overlying a particular benthic community differs between wave- and tide-dominated systems. In a simplified wave-driven reef, offshore (oceanic) water moves from reef crest to back-reef roughly unidirectionally, generally exiting the reef through channels. Thus, benthic communities are subjected to the physicochemical water properties present in offshore waters modified by the communities upstream of them. In a simplified tide-driven reef, flow direction changes throughout the tidal cycle; during flood tide, offshore waters enter the reef, while during ebb tide, waters from the back-reef traverse all downstream communities. These flow patterns control water residence times within the reef community. In wave-dominated reefs, flow speeds are driven by wave-breaking on the reef, creating residence times on the scale of $\sim$ hours; wave energy can be generally consistent in time over $\sim$ days-weeks (Lowe and Falter, 2015). In tide-dominated systems, reef waters exchange with offshore waters at timescales greater than or equal to a semidiurnal (or diurnal) tidal cycle; this residence time will vary depending on the reef's vertical position relative to mean sea level and its morphology. Finally, there are marked differences in nutrient uptake rates between wave- and tide-dominated reefs. The consistency of wave energy at scales of $\sim$ days-weeks likely drives similarly consistent mass-transfer-limited nutrient uptakes rates on wave-dominated reefs. On reefs with strong tidal forcing, however, flow speeds are highly variable throughout the tidal cycle and mass-transfer-limited uptake 
can vary by an order of magnitude within $\sim$ hours-minutes. Flow speeds also change over the spring-neap tidal cycle $(\sim 15 \mathrm{~d})$; on Tallon reef, mass-transfer-limited uptake rates were $\sim 2-4$ fold greater during spring tides relative to neap tides.

The $\sim 8 \mathrm{~m}$ tidal range of Tallon reef is typical of tidal ranges in the Kimberley region, and thus the results presented here are likely to be broadly representative of conditions experienced by many reefs $\left(\sim 2000 \mathrm{~km}^{2}\right.$ of total reef area) in this region. Most reefs globally do not experience such an "extreme" tidal regime, and therefore some aspects of this study (such as benthic fluxes varying by an order of magnitude on scales of minutes to hours) would not necessarily represent conditions on mesotidal or microtidal reefs. However, approximately $30 \%$ of reefs worldwide have tide-dominated circulation, including iconic systems such as much of the southern Great Barrier Reef (Lowe and Falter, 2015); such reefs likely experience a similar, though more moderated, version of the physical processes that occur in macrotidal systems. Our work therefore provides some insight into how other researchers may relate benthic fluxes to tidal processes on other reef systems. Further process-based studies that incorporate tidal forcing will improve predictions of reef water temperatures (and coral bleaching), in situ calcification rates, and many other physically linked biological processes that affect the health and resilience of coral reef communities.

\section{Conclusions}

In conclusion, this study was one of the first to measure rates of in situ benthic nutrient uptake and release on a tidally forced reef. We found that reef communities released a moderate amount of DIN, potentially derived from the remineralization of phytoplankton, large organic material, and DON. The strong tidal forcing of this reef drives large variability (an order of magnitude) in mass-transfer-limited nutrient uptake rates at short timescales (minutes-hours), and uptake can be enhanced in reef zones downstream of where DIN release occurs. Tallon reef displays some indications of nitrogen-limitation during the dry season, which may be relieved during the wet season; seasonal increases in offshore nitrate concentrations increased mass-transfer-limited uptake rates by a factor of $\sim 2$. This work identifies some hydrodynamic properties of tide-dominated reefs that control their biogeochemistry and help define them in comparison to wave-dominated reefs.

Data availability. The data used in this paper are publicly accessible and can be downloaded here: https://data.pawsey.org.au/public/ ?path=/WANodeOceanDataNetwork/WAMSI2/KMRP/2.2/2.2.3 (last access: 8 May 2019).
Author contributions. Field experiments were designed by RKG, RJL, and JLF. Fieldwork was conducted by RKG and RJL. RKG analyzed the results and prepared the manuscript with contributions from RJL and JLF.

Competing interests. The authors declare that they have no conflict of interest.

Acknowledgements. This work was conducted on Bardi Jawi sea country and we acknowledge the Traditional Owners past, present, and emerging who care for this country. We thank the Bardi Jawi Rangers and Kimberley Marine Research Station staff for providing assistance and local knowledge during field experiments. We thank Michael Cuttler, Jordan Iles, Miela Kolomaznik, and Leonardo Ruiz-Montoya for helping with fieldwork. Three anonymous reviewers gave helpful comments that improved earlier versions of this paper.

Financial support. This research has been supported by the Australian Research Council (Future Fellowship grant no. FT110100201), the Australian Research Council Centre of Excellence for Coral Reef Studies (grant no. CE140100020), and the Western Australian Marine Science Institution (Kimberley Marine Research Program, Project 2.2.3).

Review statement. This paper was edited by Jack Middelburg and reviewed by three anonymous referees.

\section{References}

Alldredge, A. L., Carlson, C. A., and Carpenter, R. C.: Sources of organic carbon to coral reef flats, Oceanography, 26, 108-113, 2013.

Andrews, J. C. and Gentien, P.: Upwelling as a source of nutrients for the Great Barrier Reef ecosystems: A solution to Darwin's question?, Mar. Ecol. Prog. Ser., 8, 257-269, 1982.

Atkinson, M., Kotler, E., and Newton, P.: Effects of water velocity on respiration, calcification, and ammonium uptake of a Porites compressa community, Pac. Sci., 48, 296-303, 1994.

Atkinson, M. J.: Biogeochemistry of nutrients, in: Coral reefs: An ecosystem in transition, edited by: Dubinsky, Z. and Stambler, N., Springer Netherlands, 199-206, 2011.

Atkinson, M. J. and Bilger, R. W.: Effects of water velocity on phosphate uptake in coral reef-flat communities, Limnol. Oceanogr., 37, 273-279, 1992.

Atkinson, M. J. and Falter, J. L.: Coral Reefs, in: Biogeochemistry of Marine Systems, edited by: Black, K. and Shimmield, G., CRC Press, Boca Raton, FL, 40-64, 2003.

Atkinson, M. J. and Smith, S. V.: C : N : P ratios of benthic marine plants, Limnol. Oceanogr., 28, 568-574, 1983.

Baird, M. E., Roughan, M., Brander, R. W., Middleton, J. H., and Nippard, G. J.: Mass-transfer-limited nitrate uptake on a coral 
reef flat, Warraber Island, Torres Strait, Australia, Coral Reefs, 23, 386-396, https://doi.org/10.1007/s00338-004-0404-z, 2004.

Bilger, R. and Atkinson, M.: Anomalous mass transfer of phosphate on coral reef flats, Limnol. Oceanogr., 37, 261-272, 1992.

Brodie, J., Schroeder, T., Rohde, K., Faithful, J., Masters, B., Dekker, A., Brando, V., and Maughan, M.: Dispersal of suspended sediments and nutrients in the Great Barrier Reef lagoon during river-discharge events: conclusions from satellite remote sensing and concurrent floodplume sampling, Aust. J. Mar. Freshwater Res., 61, 651-664, https://doi.org/10.1071/MF08030, 2010.

Cardini, U., Bednarz, V. N., Foster, R. A., and Wild, C.: Benthic $\mathrm{N}_{2}$ fixation in coral reefs and the potential effects of human-induced environmental change, Ecol. Evol., 4, 17061727, https://doi.org/10.1002/ece3.1050, 2014.

Cornelisen, C. D. and Thomas, F. I. M.: Prediction and validation of flow-dependent uptake of ammonium over a seagrasshardbottom community in Florida Bay, Mar. Ecol. Prog. Ser., 386, 71-81, 2009.

Cuet, P., Atkinson, M. J., Blanchot, J., Casareto, B. E., Cordier, E., Falter, J., Frouin, P., Fujimura, H., Pierret, C., Susuki, Y., and Tourrand, C.: CNP budgets of a coral-dominated fringing reef at La Réunion, France: coupling of oceanic phosphate and groundwater nitrate, Coral Reefs, 30, 45-55, https://doi.org/10.1007/s00338-011-0744-4, 2011a.

Cuet, P., Pierret, C., Cordier, E., and Atkinson, M. J.: Water velocity dependence of phosphate uptake on a coral-dominated fringing reef flat, La Réunion Island, Indian Ocean, Coral Reefs, 30, $37-$ 43, https://doi.org/10.1007/s00338-010-0712-4, 2011b.

Dandan, S. S., Falter, J. L., Lowe, R. J., and McCulloch, M. T.: Resilience of coral calcification to extreme temperature variations in the Kimberley region, northwest Australia, Coral Reefs, 34, 1151-1163, https://doi.org/10.1007/s00338-015-1335-6, 2015.

D'Elia, C. and Wiebe, W.: Biogeochemical nutrient cycles in coral reef ecosystems, in: Coral Reefs, edited by: Dubinsky, Z., Elsevier, 49-74, 1990.

Devlin, M. and Schaffelke, B.: Spatial extent of riverine flood plumes and exposure of marine ecosystems in the Tully coastal region, Great Barrier Reef, Aust. J. Mar. Freshwater Res., 60, 1109-1122, https://doi.org/10.1071/MF08343, 2009.

Falter, J. L., Atkinson, M. J., and Merrifield, M. A.: Masstransfer limitation of nutrient uptake by a wave-dominated reef flat community, Limnol. Oceanogr., 49, 1820-1831, https://doi.org/10.4319/1o.2004.49.5.1820, 2004.

Falter, J. L., Lowe, R. J., and Zhang, Z.: Toward a universal mass-momentum transfer relationship for predicting nutrient uptake and metabolite exchange in benthic reef communities, Geophys. Res. Lett., 43, 9764-9772, https://doi.org/10.1002/2016gl070329, 2016.

Ferrier, M. D.: Net uptake of dissolved free amino acids by four scleractinian corals, Coral Reefs, 10, 183-187, https://doi.org/10.1007/bf00336772, 1991.

Furnas, M., Mitchell, A., Skuza, M., and Brodie, J.: In the other $90 \%$ : phytoplankton responses to enhanced nutrient availability in the Great Barrier Reef Lagoon, Mar. Pollut. Bull., 51, 253 265, https://doi.org/10.1016/j.marpolbul.2004.11.010, 2005.

Furnas, M., Alongi, D., McKinnon, D., Trott, L., and Skuza, M.: Regional-scale nitrogen and phosphorus budgets for the northern $\left(14^{\circ} \mathrm{S}\right)$ and central $\left(17^{\circ} \mathrm{S}\right)$ Great Barrier
Reef shelf ecosystem, Cont. Shelf Res., 31, 1967-1990, https://doi.org/10.1016/j.csr.2011.09.007, 2011.

Furnas, M. M. J.: Catchments and corals: terrestrial runoff to the Great Barrier Reef, Australian Institute of Marine Science \& CRC Reef Research Centre, 350 pp., 2003.

Genin, A., Yahel, G., Reidenbach, M., Monismith, S., and Koseff, J.: Reefs revealed using the control volume approach, Oceanography, 15, 90-96, 2002.

Green, R. H., Jones, N. L., Rayson, M. D., Lowe, R. J., Bluteau, C. E., and Ivey, G. N.: Nutrient fluxes into an isolated coral reef atoll by tidally driven internal bores, Limnol. Oceanogr., 64, 461-473, 2019.

Grover, R., Maguer, J.-F., Allemand, D., and Ferrier-Pagès, C.: Uptake of dissolved free amino acids by the scleractinian coral Stylophora pistillata, J. Exp. Biol., 211, 860-865, https://doi.org/10.1242/jeb.012807, 2008.

Gruber, R. K., Lowe, R. J., and Falter, J. L.: Metabolism of a tide-dominated reef platform subject to extreme diel temperature and oxygen variations, Limnol. Oceanogr., 62, 1701-1717, https://doi.org/10.1002/lno.10527, 2017.

Gruber, R. K., Lowe, R. J., and Falter, J. L.: Benthic uptake of phytoplankton and ocean-reef exchange of particulate nutrients on a tide-dominated reef, Limnol. Oceanogr., 63, 1545-1561, https://doi.org/10.1002/lno.10790, 2018

Haas, A. F. and Wild, C.: Composition analysis of organic matter released by cosmopolitan coral reef-associated green algae, Aquat. Biol., 10, 131-138, 2010.

Hatcher, A. I. and Frith, C. A.: The control of nitrate and ammonium concentrations in a coral reef lagoon, Coral Reefs, 4, 101-110, 1985.

Houlbrèque, F., Delesalle, B., Blanchot, J., Montel, Y., and FerrierPagès, C.: Picoplankton removal by the coral reef community of La Prevoyante, Mayotte Island, Aquat. Microb. Ecol., 44, 59-70, https://doi.org/10.3354/ame044059, 2006.

Hurd, C. L.: Water motion, marine macroalgal physiology, and production, J. Phycol., 36, 453-472, https://doi.org/10.1046/j.15298817.2000.99139.x, 2000.

Jones, N. L., Patten, N. L., Krikke, D. L., Lowe, R. J., Waite, A. M., and Ivey, G. N.: Biophysical characteristics of a morphologically-complex macrotidal tropical coastal system during a dry season, Estuarine, Coast. Shelf Sci., 149, 96-108, https://doi.org/10.1016/j.ecss.2014.07.018, 2014.

Knapp, A. N., Sigman, D. M., and Lipschultz, F. C. G. B.: N isotopic composition of dissolved organic nitrogen and nitrate at the Bermuda Atlantic Time-series Study site, Global Biogeochem. Cy., 19, GB1018, https://doi.org/10.1029/2004gb002320, 2005.

Kordi, M. N. and O'Leary, M.: Geomorphic classification of coral reefs in the north western Australian shelf, Reg. Stud. Mar. Sci. 7, 100-110, https://doi.org/10.1016/j.rsma.2016.05.012, 2016.

Kowalik, Z.: Tide distribution and tapping into tidal energy, Oceanologia, 46, 291-331, 2004.

Larned, S. T.: Nitrogen- versus phosphorus-limited growth and sources of nutrients for coral reef macroalgae, Mar. Biol., 132, 409-421, https://doi.org/10.1007/s002270050407, 1998.

Larned, S. T. and Atkinson, M.: Effects of water velocity on $\mathrm{NH}_{4}$ and $\mathrm{PO}_{4}$ uptake and nutrient-limited growth in the macroalga Dictyosphaeria cavernosa, Mar. Ecol. Prog. Ser., 157, 295-302, 1997. 
Lehrter, J. C. and Cebrian, J.: Uncertainty propagation in an ecosystem nutrient budget, Ecol. Appl., 20, 508-524, 2010.

Leichter, J. J., Stewart, H. L., and Miller, S. L.: Episodic nutrient transport to Florida coral reefs, Limnol. Oceanogr., 48, 13941407, https://doi.org/10.4319/lo.2003.48.4.1394, 2003.

Leichter, J. J., Aldredge, A. L., Bernardi, G., Brooks, A. J., Carlson, C. A., Carpenter, R. C., Edmunds, P. J., Fewings, M. R., Hanson, K. M., Hench, J. L., Holbrook, S. J., Nelson, C. E., Schmitt, R. J., Toonen, R. J., Washburn, L., and Wyatt, A. S. J.: Biological and physical interactions on a tropical island coral reef: Transport and retention processes on Moorea, French Polynesia, Oceanography, 26, 52-63, 2013.

Lentz, S. J., Davis, K. A., Churchill, J. H., and DeCarlo, T. M.: Coral reef drag coefficients-water depth dependence, J. Phys. Oceanogr., 47, 1061-1075, https://doi.org/10.1175/JPO-D-160248.1, 2017.

Li, Y.-H. and Gregory, S.: Diffusion of ions in sea water and in deepsea sediments, Geochim. Cosmochim. Ac., 38, 703-714, 1974.

Lowe, R. J. and Falter, J. L.: Oceanic forcing of coral reefs, Annu. Rev. Mar. Sci., 7, 43-66, https://doi.org/10.1146/annurevmarine-010814-015834, 2015.

Lowe, R. J., Leon, A. S., Symonds, G., Falter, J. L., and Gruber, R.: The intertidal hydraulics of tide-dominated reef platforms, J. Geophys. Res.-Oceans, 120, 4845-4868, https://doi.org/10.1002/2015jc010701, 2015.

Lowe, R. J., Pivan, X., Falter, J., Symonds, G., and Gruber, R.: Rising sea levels will reduce extreme temperature variations in tide-dominated reef habitats, Sci. Adv., 2, e1600825, https://doi.org/10.1126/sciadv.1600825, 2016.

McDonald, C., Koseff, J., and Monismith, S.: Effects of the depth to coral height ratio on drag coefficients for unidirectional flow over coral, Limnol. Oceanogr., 51, 1294-1301, 2006.

McKinnon, A. D., Logan, M., Castine, S. A., and Duggan, S.: Pelagic metabolism in the waters of the Great Barrier Reef, Limnol. Oceanogr., 58, 1227-1242, 2013.

McMahon, K. W., Thorrold, S. R., Houghton, L. A., and Berumen, M. L.: Tracing carbon flow through coral reef food webs using a compound-specific stable isotope approach, Oecologia, 180, 809-821, https://doi.org/10.1007/s00442-015-3475-3, 2016.

Miyajima, T., Hata, H., Umezawa, Y., Kayanne, H., and Koike, I.: Distribution and partitioning of nitrogen and phosphorus in a fringing reef lagoon of Ishigaki Island, northwestern Pacific, Mar. Ecol. Prog. Ser., 341, 45-57, 2007a.

Miyajima, T., Tanaka, Y., Koike, I., Yamano, H., and Kayanne, H.: Evaluation of spatial correlation between nutrient exchange rates and benthic biota in a reef-flat ecosystem by GIS-assisted flow-tracking, J. Oceanogr., 63, 643-659, https://doi.org/10.1007/s10872-007-0057-y, 2007b.

Monismith, S.: Hydrodynamics of coral reefs, Annu. Rev. Fluid Mech., 39, 37-55, https://doi.org/10.1146/annurev.fluid.38.050304.092125, 2007.

Parrish, J. D.: Fish communities of interacting shallow-water habitats in tropical oceanic regions, Mar. Ecol. Prog. Ser., 58, 143160, 1989.

Paytan, A., Shellenbarger, G. G., Street, J. H., Gonneea, M. E., Davis, K., Young, M. B., and Moore, W. S.: Submarine groundwater discharge: An important source of new inorganic nitrogen to coral reef ecosystems, Limnol. Oceanogr., 51, 343-348, https://doi.org/10.4319/1o.2006.51.1.0343, 2006.
Pedersen, O., Colmer, T. D., Borum, J., Zavala-Perez, A., and Kendrick, G. A.: Heat stress of two tropical seagrass species during low tides-impact on underwater net photosynthesis, dark respiration and diel in situ internal aeration, New Phytol., 210, 1207-1218, 2016.

Rasheed, M., Badran, M. I., Richter, C., and Huettel, M.: Effect of reef framework and bottom sediment on nutrient enrichment in a coral reef of the Gulf of Aqaba, Red Sea, Mar. Ecol. Prog. Ser., 239, 277-285, 2002.

Reidenbach, M. A., Monismith, S. G., Koseff, J. R., Yahel, G., and Genin, A.: Boundary layer turbulence and flow structure over a fringing coral reef, Limnol. Oceanogr., 51, 1956-1968, https://doi.org/10.4319/lo.2006.51.5.1956, 2006.

Ribes, M., Coma, R., Atkinson, M. J., and Kinzie, R. A.: Sponges and ascidians control removal of particulate organic nitrogen from coral reef water, Limnol. Oceanogr., 50, 1480-1489, 2005.

Richards, Z. T., Garcia, R. A., Wallace, C. C., Rosser, N. L., and Muir, P. R.: A diverse assemblage of reef corals thriving in a dynamic intertidal reef setting (Bonaparte Archipelago, Kimberley, Australia), PLoS ONE, 10, e0117791, https://doi.org/10.1371/journal.pone.0117791, 2015.

Rix, L., de Goeij, J. M., van Oevelen, D., Struck, U., Al-Horani, F. A., Wild, C., and Naumann, M. S.: Differential recycling of coral and algal dissolved organic matter via the sponge loop, Funct. Ecol., 31, 778-789, https://doi.org/10.1111/1365-2435.12758, 2017.

Sansone, F. J., Tribble, G. W., Andrews, C. C., and Chanton, J. P.: Anaerobic diagenesis within recent, Pleistocene, and Eocene marine carbonate frameworks, Sedimentology, 37, 997-1009, 1990.

Santos, I. R., Glud, R. N., Maher, D., Erler, D., and Eyre, B. D.: Diel coral reef acidification driven by porewater advection in permeable carbonate sands, Heron Island, Great Barrier Reef, Geophys. Res. Lett., 38, L03604, https://doi.org/10.1029/2010g1046053, 2011.

Schaffelke, B., Carleton, J., Skuza, M., Zagorskis, I., and Furnas, M. J.: Water quality in the inshore Great Barrier Reef lagoon: Implications for long-term monitoring and management, Mar. Pollut. Bull., 65, 249-260, https://doi.org/10.1016/j.marpolbul.2011.10.031, 2012.

Schroeder, T., Devlin, M. J., Brando, V. E., Dekker, A. G., Brodie, J. E., Clementson, L. A., and McKinna, L.: Interannual variability of wet season freshwater plume extent into the Great Barrier Reef lagoon based on satellite coastal ocean colour observations, Mar. Pollut. Bull., 65, 210-223, https://doi.org/10.1016/j.marpolbul.2012.02.022, 2012.

Silverman, J., Kline, D. I., Johnson, L., Rivlin, T., Schneider, K., Erez, J., Lazar, B., and Caldeira, K.: Carbon turnover rates in the One Tree Island reef: A 40-year perspective, J. Geophys. Res.Biogeosci., 117, G03023, https://doi.org/10.1029/2012jg001974, 2012.

Smith, S. V.: Phosphorus versus nitrogen limitation in the marine environment, Limnol. Oceanogr., 29, 1149-1160, 1984.

Southwell, M. W., Weisz, J. B., Martens, C. S., and Lindquist, N.: In situ fluxes of dissolved inorganic nitrogen from the sponge community on Conch Reef, Key Largo, Florida, Limnol. Oceanogr., 53, 986-996, https://doi.org/10.4319/lo.2008.53.3.0986, 2008.

Strickland, J. D. H. and Parsons, T. R.: A practical handbook of seawater analysis, Fisheries Research Board of Canada, Ottawa, Ontario, 1972. 
Stuhldreier, I., Sánchez-Noguera, C., Rixen, T., Cortés, J., Morales, A., and Wild, C.: Effects of seasonal upwelling on inorganic and organic matter dynamics in the water column of Eastern Pacific coral reefs, PLOS ONE, 10, e0142681, https://doi.org/10.1371/journal.pone.0142681, 2015.

Szmant, A. M.: Nutrient enrichment on coral reefs: Is it a major cause of coral reef decline?, Estuaries, 25, 743-766, https://doi.org/10.1007/bf02804903, 2002.

Tait, D. R., Erler, D. V., Santos, I. R., Cyronak, T. J., Morgenstern, U., and Eyre, B. D.: The influence of groundwater inputs and age on nutrient dynamics in a coral reef lagoon, Mar. Chem., 166, 36-47, https://doi.org/10.1016/j.marchem.2014.08.004, 2014.

Tanaka, Y., Ogawa, H., and Miyajima, T.: Production and bacterial decomposition of dissolved organic matter in a fringing coral reef, J. Oceanogr., 67, 427-437, https://doi.org/10.1007/s10872011-0046-z, 2011.

Thibodeau, B., Miyajima, T., Tayasu, I., Wyatt, A. S. J., Watanabe, A., Morimoto, N., Yoshimizu, C., and Nagata, T.: Heterogeneous dissolved organic nitrogen supply over a coral reef: First evidence from nitrogen stable isotope ratios, Coral Reefs, 32, 1103 1110, https://doi.org/10.1007/s00338-013-1070-9, 2013.

Thomas, F. I. M. and Atkinson, M. J.: Ammonium uptake by coral reefs: Effects of water velocity and surface roughness on mass transfer, Limnol. Oceanogr., 42, 81-88, 1997.

Tribble, G. W., Sansone, F. J., and Smith, S. V.: Stoichiometric modeling of carbon diagenesis within a coral reef framework, Geochim. Cosmochim. Ac., 54, 2439-2449, https://doi.org/10.1016/0016-7037(90)90231-9, 1990.

Valderrama, J. C.: The simultaneous analysis of total nitrogen and total phosphorus in natural waters, Mar. Chem., 10, 109-122, 1981.
Vonk, J. A., Middelburg, J. J., Stapel, J., and Bouma, T. J.: Dissolved organic nitrogen uptake by seagrasses, Limnol. Oceanogr., 53, 542-548, https://doi.org/10.4319/lo.2008.53.2.0542, 2008.

Wang, Y.-H., Dai, C.-F., and Chen, Y.-Y. C. L.: Physical and ecological processes of internal waves on an isolated reef ecosystem in the South China Sea, Geophys. Res. Lett., 34, L18609, https://doi.org/10.1029/2007gl030658, 2007.

Wells, F., Hanley, J. R., and Walker, D. I.: Marine biological survey of the southern Kimberley, Western Australia, Western Australian Museum, 1995.

Wyatt, A. S. J., Lowe, R. J., Humphries, S., and Waite, A. M.: Particulate nutrient fluxes over a fringing coral reef: Relevant scales of phytoplankton production and mechanisms of supply, Mar. Ecol. Prog. Ser., 405, 113-130, https://doi.org/10.3354/meps08508, 2010.

Wyatt, A. S. J., Falter, J. L., Lowe, R. J., Humphries, S., and Waite, A. M.: Oceanographic forcing of nutrient uptake and release over a fringing coral reef, Limnol. Oceanogr., 57, 401-419, 2012.

Zhang, Z., Lowe, R., Falter, J., and Ivey, G.: A numerical model of wave- and current-driven nutrient uptake by coral reef communities, Ecol. Model., 222, 1456-1470, https://doi.org/10.1016/j.ecolmodel.2011.01.014, 2011.

Ziegler, S. and Benner, R.: Dissolved organic carbon cycling in a subtropical seagrass-dominated lagoon, Mar. Ecol. Prog. Ser., 180, 149-160, 1999. 